\title{
Comparison of urinary protein-to-creatinine ration, serum albumin, serum creatinine and systolic arterial blood pressure of glomerular injury cases in dogs with chronic kidney disease
}

\section{Comparação da razão proteína creatinina urinárias, albumina sérica, creatinina sérica e pressão arterial sistólica das lesões glomerulares encontradas em cães com doença renal crônica}

Paula Bilbau Sant'Anna'; Fabricio da Silva Trindade ${ }^{2}$; Silvano Salgueiro Geraldes ${ }^{1}$; Maria Gabriela Picelli de Azevedo'; Alessandre Hataka3; Antonio Carlos Paes4; Alessandra Melchert ${ }^{3}$; Priscylla Tatiana Chalfun Guimarães-Okamoto ${ }^{3 *}$

\section{Highlights}

Assessment of glomerular alterations that may be present in CKD in dogs.

Comparision of UPC, albumin, creatinine and blood pressure in CKD and glomerular disease.

The study can be used to improve the complications and consequences of glomerular disease.

\begin{abstract}
This study aims at assessing the prevalence of glomerular alterations in dogs with chronic kidney disease (CKD) and comparing the clinical and laboratory parameters. The tests conducted include a double-blind histopathological assay conducted by two pathologists, urine tests including inactive sediment, urinary protein-to-creatinine (UPC), serum albumin and serum creatinine, as well as measurement of the systolic arterial blood pressure. The prevalence of glomerular injuries was determined and the predominant injury was compared with a group comprised of the remaining injuries. The study included 24 dogs with CKD. The results revealed a predominance of membranous glomerular alterations $17 / 24$ (70,83\%), followed by glomerulosclerosis $3 / 24$ (12,50\%), membranoproliferative injuries $2 / 24$, glomerulocystic atrophy $1 / 24$ and

1 Students of the Master's Course of Post-Graduate Veterinary Medicine Program in School of Veterinary Medicine and Animal Sciences, Universidade Estadual de São Paulo, UNESP, Botucatu, SP, Brazil. E-mail: pbilba@gmail.com; silvano.geraldes@unesp.br, gabipicellia@gmail.com

2 Veterinary Pathologist, São Caetano do Sul, SP, Brazil. E-mail: fabricio.silvatrindade@gmail.com

${ }^{3}$ Profs. Drs. of Depatment of Veterinary Clinic in School of Veterinary Medicine and Animal Sciences, UNESP, Botucatu, SP, Brazil. E-mail: a.hataka@unesp.br; alessandra.melchert@unesp.br; tatiana.okamoto@unesp.br

${ }^{4}$ Prof. Dr. of Depatment of Veterinary Hygiene and Public Health in School of Veterinary Medicine and Animal Science, UNESP, Botucatu, SP, Brazil. E-mail: ac.paes@unesp.br

* Author for correspondence
\end{abstract}

Received: June 15, 2020 - Approved: Apr. 14, 2021 
glomerular amyloidosis 1/24. Amyloidosis presented the highest UPC while the membranoproliferative injury presented the lowest mean concentration of serum albumin. Higher values in the UPC did not correspond with lower mean serum albumin values. Glomerulosclerosis presented the highest mean systolic blood pressure and glomerular atrophy presented the highest creatinine values. When comparing membranous injuries with a group comprised of the remaining injuries, the UPC did not present significant differences between the groups. Renal amyloidosis was included in the group with the lowest systolic arterial blood pressure values while membranoproliferative injury was included in the group with highest UPC. The group called "others" presented the highest creatinine value. Dogs with CKD may present several types of glomerular injuries with similar clinical and laboratory profiles. This study observed a predominance of membranous glomerular injuries, followed by membranoproliferative injuries, glomerulocystic atrophy and amyloidosis.

Key words: Amyloidosis. Dogs. Glomerulocystic. Glomerulopathy. Glomerulus.

\section{Resumo}

O estudo teve como objetivo avaliar a prevalência das alterações glomerulares dos cães doentes renais crônicos e comparar parâmetros clínicos e laboratoriais. Foi realizada análise histopatológica por dois patologistas pelo método duplo-cego, análise dos exames de urina com sedimento inativo, razão proteína creatinina urinárias, avaliação da creatinina e albumina séricas e pressão arterial sistólica. Determinouse a prevalência das lesões glomerulares e foi comparado o grupo de lesões predominante com um grupo abrangendo as demais lesões. Foram incluídos neste estudo 24 cães doentes renais crônicos. Após análise foi observado predomínio de alterações glomerulares membranosas $(n=17)$, seguidos de glomeruloesclerose $(n=3)$, lesões membranoproliferativas $(n=2)$, atrofia glomerulocística $(n=1)$ e amiloidose glomerular $(n=1)$. A amiloidose apresentou maior razão proteína creatinina urinárias e a lesão membranoproliferativa obteve a menor média de albumina sérica. Maiores valores da razão proteína creatinina urinárias não corresponderam com menor média de albumina sérica. Glomeruloesclerose teve maior média de pressão arterial sistólica. O maior valor de creatinina foi observado no caso de atrofia glomerular. Quando comparados lesões membranosas com um grupo dos demais tipos de lesões, RPC não diferiu entre os grupos. Amiloidose renal estava inclusa no grupo de animais com valores mais baixos de pressão arterial sistólica e a lesão membranoproliferativa estava entre os animais com maior RPC. O grupo denominado "outros" teve maior valor de creatinina. Cães com doença renal crônica podem apresentar diferentes tipos de lesões glomerulares com quadros clínicos e laboratoriais semelhantes. Há um predomínio de lesões glomerulares membranosas, seguidas pela glomeruloesclerose, lesão membranoproliferativa, atrofia glomerulocística e amiloidose.

Palavras-chave: Amiloidose. Atrofria glomerulocistica. Canídeos. Glomérulo. Lesão glomerular.

\section{Introduction}

Chronic Kidney Disease affects dogs in all age groups, but is more frequent in older animals, causing irreversible functional and structural damage in the kidneys (Bartges, 2012). Chronicity is determined though laboratory findings, physical examinations, alterations in imaging examinations or an histopathological assay verifying glomerular 
disease (Polzin, 2013; Hokamp et al., 2016). The disease is classified in four stages based on serum creatinine and symmetric dimethylarginine (SDMA) according to the International Renal Interest Society (IRIS) guidelines, and subclassified based in the values for urinary protein-to-creatinine ration and systolic arterial blood pressure (Polzin, 2013; International Renal Interest Society [IRIS], 2019).

Proteinuria acts as a 'sentinel' of sorts in cases of infectious diseases associated with glomerulopathies, such as Lyme disease in North America and Leishmaniosis in the Mediterranean (Polzin \& Cowgill, 2013) and in Brazil, to which it is endemic, with several reports in the Americas (Maia-Elkhoury et.al., 2008). Glomerular alterations have also been observed in Brazil in dogs with ehrlichiosis (Silva et al., 2015), as both canine monocytic ehrlichiosis (Santos et al., 2009) and babesiosis (Cavalcante et al., 2006) are endemic to the country. Further research regarding alterations caused by these diseases, such as glomerulopathies, may represent an important population not only for the area, but for other endemic areas around the world.

Systemic arterial hypertension occurs in 65 to $75 \%$ of the animals affected by CKD (Bartges, 2012). The kidneys are considered one of the target organs for hypertension damage and once the hypertension is verified, it may lead to increased proteinuria, decreased kidney function, increased uremic crises and increased mortality (Vaden \& Elliott, 2016).

For dogs, kidney biopsy is the most indicated technique to assess glomerular diseases (R. E. Cianciolo et al., 2016a) since most forms of glomerular diseases can be differentiated through histopathological findings (Aresu et al., 2008), which aids in choosing the ideal therapy for each case and resolving the disease (Jennette \& Schwarts, 2007).

This study aims at assessing glomerular alterations in dogs with naturallyoccurring chronic kidney disease, determining the prevalence of glomerular injuries and classifying them, in addition to assessing and comparing UPC, serum albumin, serum creatinine and systolic arterial blood pressure in order to verify possible differences in these parameters between animals with the predominant type of injury (membranous) and the group comprised of the remaining glomerular injuries observed.

\section{Materials and Methods}

\section{Animals and experimental design}

The study included 24 dogs without breed, sex or age predilection, all of which were diagnosed with Stage 1 to 4 chronic kidney disease according to the IRIS staging definitions (IRIS, 2019) and all of which died between January 2012 and December 2018 at the Veterinary Hospital at FMVZ - UNESP, Botucatu, Brazil. A necropsy was conducted and representative fragments were collected from the kidneys.

Exclusion criteria for the study were possibility of active infection in the urinary tract (based on urine sediment or urine culture findings), hematuria (macroscopic or microscopic exceeding 100 erythrocytes per 40x magnification field) and pyuria (over 10 leukocytes per 40x magnification field) detected on the examinations conducted on the last four weeks before death? 


\section{Clinical and laboratory analysis}

In addition to the histopathological analysis, the study also assessed laboratory parameters (urine examination, serum creatinine and albumin, urinary protein-tocreatinine ratio) and clinical parameters (systolic arterial blood pressure) to establish possiblecorrelationswiththehistopathological results.

To determine the urinary creatinine concentration, urine samples was diluted in saline to achieve linearity and added picric acid, turning in creatinine picrate with $515 \mathrm{~nm}$ wavelength in an automatic analyzer. The pyrogallol red technique was used to determine urinary protein concentration. After centrifuging the urine, the supernatant was used to perform the test using the pyrogallol red technique and an spectrophotometer at $600 \mathrm{~nm}$ wavelength.

Serum albumin was determined by green bromocresol methodology and an spectrophotometer at $630 \mathrm{~nm}$ wavelength and serum creatinine was determined by enzymatic trinder methodology and an spectrophotometer primary wavelength at $546 \mathrm{~nm}$ and secondary 800nm.

\section{Histopathological analysis}

The kidney fragments were fixed in 10\% formalin solution for a period not exceeding 48 hours and then submitted to the routine histopathological process with washing, dehydration, diaphanization, impregnation, creation of paraffin blocks and microtomy $(R$. E. Cianciolo et al., 2016a). Afterwards, semiserialized histological cuts were made with $12 \mu \mathrm{m}$ intervals between each cut measuring
$3 \mu \mathrm{m}$ and $8 \mu \mathrm{m}$ in thickness. The cuts were positioned in histological slides ( 2 to 3 cuts per slide), placed in an oven at $60^{\circ} \mathrm{C}$ to remove the paraffin and then stained through the following histochemical techniques: Hematoxylin \& Eosin (HE), Masson's Trichrome, Periodic Acid - Schiff (PAS) and Congo Red (Cianciolo et al., 2013, R. Cianciolo, Hokamp, \& Nabity, 2016b).

The injuries were analyzed through optical microscopy in a double-blind test by two pathologists, both unaware of the correspondence between the slides analyzed and the values of the clinical and laboratory examinations, who should have reached the same diagnosis. In case of discordance, the slides were reviewed and the diagnosis reached by consensus. The injuries were classified as per R. E. Cianciolo et al. (2016a) as: $0=$ absent; and $1=$ present. The interstitial and vascular glomerular regions were observed for each sample, and the glomerular tufts at the periphery of the glomerulus were evaluated for their shape. The distribution of glomerular injuries was classified as focused or diffuse, and the degree of involvement of the glomerulus was classified as segmental or global. Hypercellularity was classified as mesangial, endocapillary or both. The presence of synechia and hyalinosis of the basement membrane of the glomerulus.

The histochemical stains were used to aid in the classification and grading of the glomerular injuries and, whenever possible, in the determination of the kidney disease, with Masson's Trichrome being used to determine the presence of conjunctive tissue in the kidneys, PAS used to identify the thickening of the glomerular capsule in glomerular diseases and Congo Red used to detect amyloid in the injured kidneys. 


\section{Statistical analysis}

The groups were analyzed statistically and compared with each other by comparing the medians through Student's t-test, employing the Wilcoxon - Mann-Whitney nonparametric test for independent samples. The results were then organized into tables.

\section{Results and Discussion}

A total of twelve females and twelve males were evaluated, with a mean age of $9.3 \pm 4.0$ years. Among the animals assessed there were 14 mixed-breeds, three Labrador Retrievers, one Beagle, one Schnauzer, one Dogo Argentino, one Shar-Pei, one Pitt Bull, one Chow Chow and one Poodle.

Regarding the CKD staging, 2/24 of the dogs were diagnosed with Stage I, $100 \%$ of which presented membranous injuries; 4/24 (16.67\%) with Stage III, 100\% of which presented membranous injuries; and 18/24 (75\%) with Stage IV, of which $1 / 18$ animal presented amyloidosis, $1 / 18$ presented glomerular atrophy, 2/18 (11.11\%) presented membranoproliferative injuries, 3/18 (16.66\%) presented glomerulosclerosis, and the remaining $11 / 18(61.11 \%)$ presented membranous injuries. One of the animals with Stage I CKD died due to trauma and the other due to oncological procedure.

The mean creatinine value for the dogs in the study was $7.36 \pm 4.08 \mathrm{mg} / \mathrm{dL}$. About $8 / 24$ (33.33\%) of the dogs presented hypertension with values exceeding $140 \mathrm{mmHg}$ (Acierno et al., 2018), while $5 / 24$ (20.83\%) of the dogs had no data regarding blood pressure and the remaining 11/24 (45.84\%) presented systolic blood pressure values within the reference for the species. The mean blood pressure for the animals evaluated was $144 \pm 29.08 \mathrm{mmHg}$ (IRIS, 2019) (Table 1).

Proteinuria $(\mathrm{RPC}>0.5)$ was observed in $24 / 24$ (100\%) of the cases. Mean proteinuria was $3.35 \pm 4.0$, showing a high likelihood of glomerular disease. The serum albumin of the dogs included in the study presented a mean value of $2.16 \pm 0.44 \mathrm{~g} / \mathrm{dL}$. UPC values exceeding 2.0 were observed in this study and are considered a strong indication of glomerular disease (R. Cianciolo et al., 2016b). 
Table 1

Scores for clinical and laboratory parameters in 24 dogs with CKD according with the predominant glomerular injury

\begin{tabular}{|c|c|c|c|c|c|}
\hline Parameter & $\begin{array}{l}\text { Amyloidosis } \\
\quad(n=1)\end{array}$ & $\begin{array}{l}\text { Glomerulocystic } \\
\text { atrophy }(n=1)\end{array}$ & $\begin{array}{l}\text { Glomerulosclerosis } \\
\qquad(n=3)\end{array}$ & $\begin{array}{l}\text { Membrano } \\
\text { proliferative } \\
\quad(n=2)\end{array}$ & $\begin{array}{l}\text { Membranous } \\
(n=17)\end{array}$ \\
\hline \multicolumn{6}{|l|}{ Albumin (g/dL) } \\
\hline Median & 2.5 & 2.4 & 2.3 & 2.05 & 2.1 \\
\hline Minimum-Maximum & $\mathrm{n} / \mathrm{a}$ & $\mathrm{n} / \mathrm{a}$ & $2-2.13$ & $2-2.1$ & $1.3-3.1$ \\
\hline \multicolumn{6}{|l|}{$\mathrm{RPC}$} \\
\hline Median & 20.22 & 2.6 & 1.70 & 4.31 & 2.22 \\
\hline Minimum-Maximum & $\mathrm{n} / \mathrm{a}$ & $\mathrm{n} / \mathrm{a}$ & $1.04-2.52$ & $1.95-6.66$ & $0.52-5.9$ \\
\hline \multicolumn{6}{|l|}{ Creatinine (mg/dL) } \\
\hline Median & 8 & 13 & 9.94 & 10.66 & 5.82 \\
\hline Minimum-Maximum & $\mathrm{n} / \mathrm{a}$ & $\mathrm{n} / \mathrm{a}$ & $5-11$ & 13 & $0.69-14$ \\
\hline \multicolumn{6}{|l|}{ Pressure (mmHg) } \\
\hline Median & 140 & 130 & 150 & 140 & 145 \\
\hline Minimum-Maximum & $\mathrm{n} / \mathrm{a}$ & $\mathrm{n} / \mathrm{a}$ & $125-200$ & $\mathrm{n} / \mathrm{a}$ & $90-190$ \\
\hline
\end{tabular}

The values are presented as median, minimum and maximum.

The histopathological evaluation through optical microscopy revealed membranous injury in $17 / 24$ (70.83\%) of the cases, glomerulosclerosis in 3/24 (12.5\%), membranoproliferative injuries in 2/ 24, glomerulocystic atrophy in $1 / 24$ and amyloidosis in 1/24.

The pathologists agreed in 21 cases, while three cases had to be reviewed for a consensus to be reached. Concordance between the diagnoses was also measured through the Kappa coefficient. The Kappa for diagnosis concordance was 0.732 , which represents a strong concordance.

The interstitial and vascular glomerular regions, distribution of glomerular injuries, glomerular hypercellularity and presence of synechia and hyalinosis of the basement membrane of the glomerulus for each classification can be seen in Table 2.
One Shar-Pei dog was diagnosed with amyloidosis (Figures 1), with the microscopic evaluation revealing a marked mesangial expansion colored in light pink in PAS and areas varying from blue to red in Masson's Trichrome. The Congo Red stain confirmed the presence of amyloid material near the glomeruli, presenting refringence when analyzed under polarized light.

In this case, the glomerulus was globally affected, with proteinaceous material in the tubules and glomerular capsular space. In addition, the same animal presented severe proteinuria, normal arterial blood pressure and serum albumin levels slightly below the reference values for the species.

The amyloid proteins may accumulate in several organs (Szczepankiewiczetal., 2018), with the kidney being one of the most common and oftentimes the only organ affected. The 
glomeruli are often the most affected part, but the cortical and medullary interstitium are also frequently involved (Slauson, Gribble, \& Russell, 1970). However, in Shar-Pei dogs, the deposition of amyloid protein in the medullary region is common (DiBartola, Tarr, Webb, \&
Giger, 1990). The breed presents a familial and hereditary disorder known as Shar-Pei fever, which favors the occurrence of amyloidosis (Rivas, Tintle, Kimball, Scarlett, \& Quimby, 1992).

\section{Table 2}

\section{Scores of the evaluated parameters in the glomeruli in optical microscopy}

\begin{tabular}{|c|c|c|c|c|c|}
\hline Parameter & $\begin{array}{l}\text { Amyloidosis } \\
\qquad(n=1)\end{array}$ & $\begin{array}{l}\text { Glomerulocystic } \\
\text { atrophy }(n=1)\end{array}$ & $\begin{array}{l}\text { Glomerulosclerosis } \\
\qquad(\mathrm{n}=3)\end{array}$ & $\begin{array}{l}\text { Membranous } \\
(n=17)\end{array}$ & $\begin{array}{c}\text { Membrano } \\
\text { proliferative } \\
\quad(n=2)\end{array}$ \\
\hline \multicolumn{6}{|l|}{ Hypercellularity } \\
\hline Mesangial & 0 & 0 & 0 & 1 & 2 \\
\hline Endocapillary & 0 & 0 & 0 & 0 & 2 \\
\hline \multicolumn{6}{|c|}{ Basement membrane thickening } \\
\hline Capsule & 0 & 1 & 2 & 13 & 2 \\
\hline Mesangial & 1 & 1 & 1 & 15 & 2 \\
\hline Capillary & 0 & 0 & 0 & 4 & 1 \\
\hline Pyknotic nuclei & 0 & 0 & 1 & 10 & 1 \\
\hline Synechia & 1 & 1 & 0 & 10 & 1 \\
\hline Hyalinosis & 0 & 0 & 0 & 1 & 0 \\
\hline \multicolumn{6}{|l|}{ Associated collagen } \\
\hline Capsule & 0 & 0 & 2 & 9 & 1 \\
\hline Glomerulus & 0 & 0 & 2 & 8 & 0 \\
\hline \multicolumn{6}{|l|}{ Proportion } \\
\hline Global & 1 & 1 & 2 & 9 & 2 \\
\hline Segmental & 0 & 0 & 1 & 8 & 0 \\
\hline Sclerosed glomeruli & 0 & 0 & 3 & 6 & 2 \\
\hline \multicolumn{6}{|c|}{ Proteinaceous material } \\
\hline Glomerulus & 1 & 1 & 1 & 14 & 2 \\
\hline Tubule & 1 & 1 & 3 & 13 & 2 \\
\hline \multicolumn{6}{|l|}{ Interstitium } \\
\hline Fibrosis & 1 & 1 & 3 & 16 & 2 \\
\hline Inflammation & 1 & 1 & 3 & 17 & 2 \\
\hline Cysts & 0 & 1 & 2 & 5 & 1 \\
\hline Crystals & 0 & 0 & 1 & 7 & 2 \\
\hline Calcification & 1 & 0 & 2 & 9 & 2 \\
\hline
\end{tabular}

The values are presented as the total number of cases presenting the alteration and the percentage they represent in the group based on the assessment of at least 20 glomeruli per animal. 
R. E. Cianciolo et al. (2016a) have also observed high UPC in animals with amyloidosis, corroborating the findings of this study, the mean UPC values of other glomerular alterations were higher. Serum albumin was discretely lower than the reference values for the species, which differs from the observations of R. E. Cianciolo et al. (2016a) who observed mean albumin values that were markedly lower than the reference.

One case of glomerular atrophy was also observed (Figures 2), presenting the highest serum creatinine value observed in this study. The systolic arterial blood pressure remained within the reference for the species, while the animal presented UPC of 2.6 and discrete hypoalbuminemia.

There are few reports of glomerulocystic kidney disease in dogs and in other species probably because it is a sporadic disease that is easily mistaken by other cystic kidney diseases, associated or not with kidney injury (Salinas, Ramírez, Ortuño, Díaz, \& González, 2008). Takahashi et al. (2005) also observed thickening and irregularity in the basement membrane of Bowman's capsule, with calcification areas associated with an apparent stenosis of the urinary pole.
It has been suggested the cystic dilations observed with glomerular atrophy are a consequence of periglomerular and interstitial fibrosis, which may compress the region of the urinary pole (Takahashi et al., 2005), or secondary to ischemic injuries caused by the obstruction of the proximal tubule (Salinas et al., 2008). Cystic dilation may be caused by malformations leading the obstruction and subsequent increased pressure in Bowman's space (Salinas et al., 2008). Kidney injuries are observed when the glomerular atrophy and retraction, both consequences of the accumulation of liquid in the urinary space (Chalifoux, Phaneuf, Olivieri, \& Gosselin, 1982), reach over $75 \%$ of the nephrons, promoting the accumulation of toxins (Confer \& Panciera, 2001).

Glomerulosclerosis (Figures 3) was the predominant injury in three dogs, with notable findings including the lower mean value for UPC and the higher systolic arterial blood pressure. In all three cases there was proteinaceous material in the tubules, while only one presented proteinaceous material in the glomerular capsular space. 


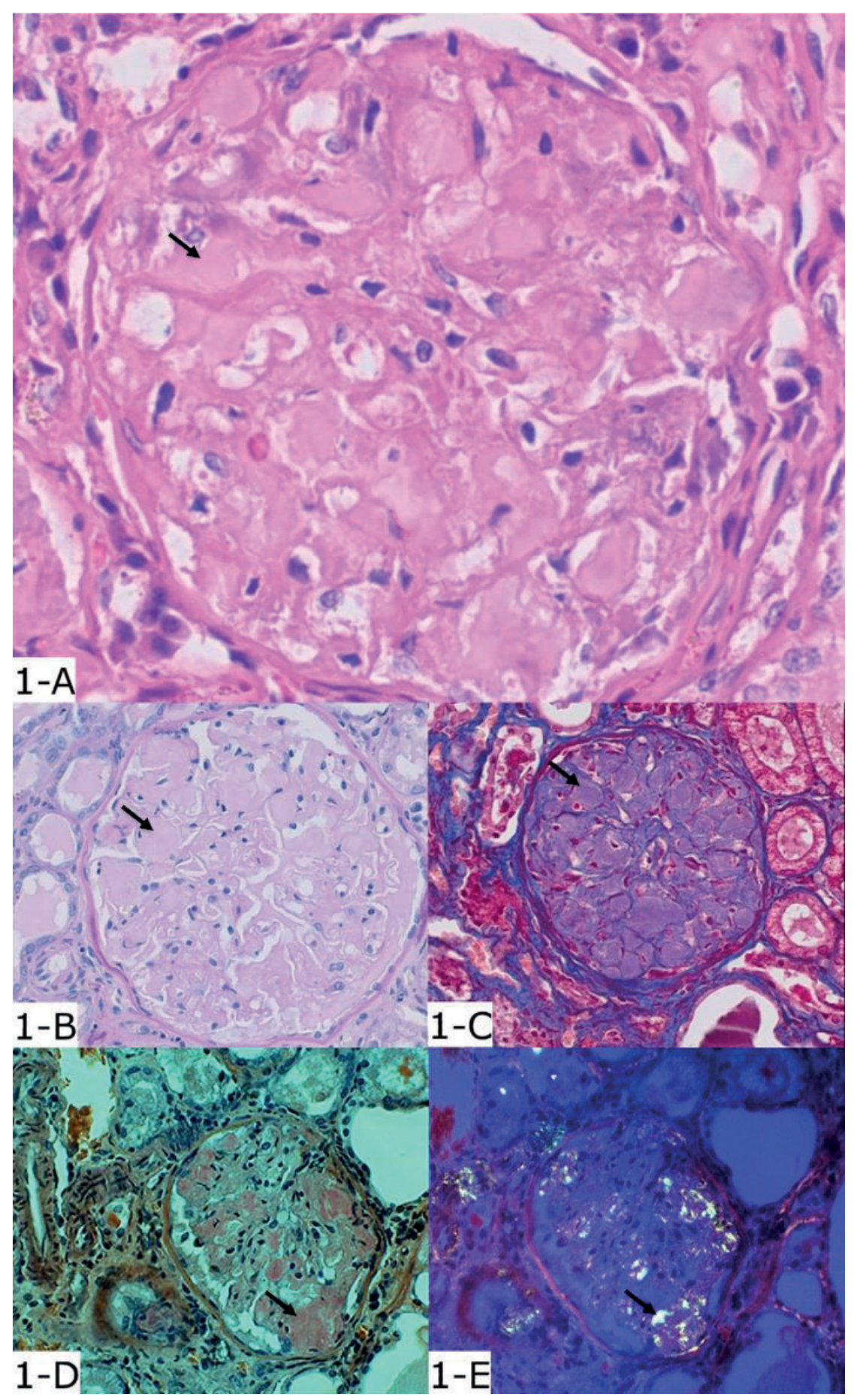

Figure 1. (A-E): Glomerular amyloidosis, dog. 400X magnification. A: The material expanding the mesangium is eosinophilic (arrow) in the Hematoxylin \& Eosin (HE) stain. B: The same material appears in a light pink color in the Periodic Acid - Schiff (PAS) stain. C: The material appears in an off-blue color in Masson's Trichrome stain. D: The material is congophilic in the Congo Red stain. E: The material presents green bi-refringence in the Congo Red stain when observed with polarized light. 


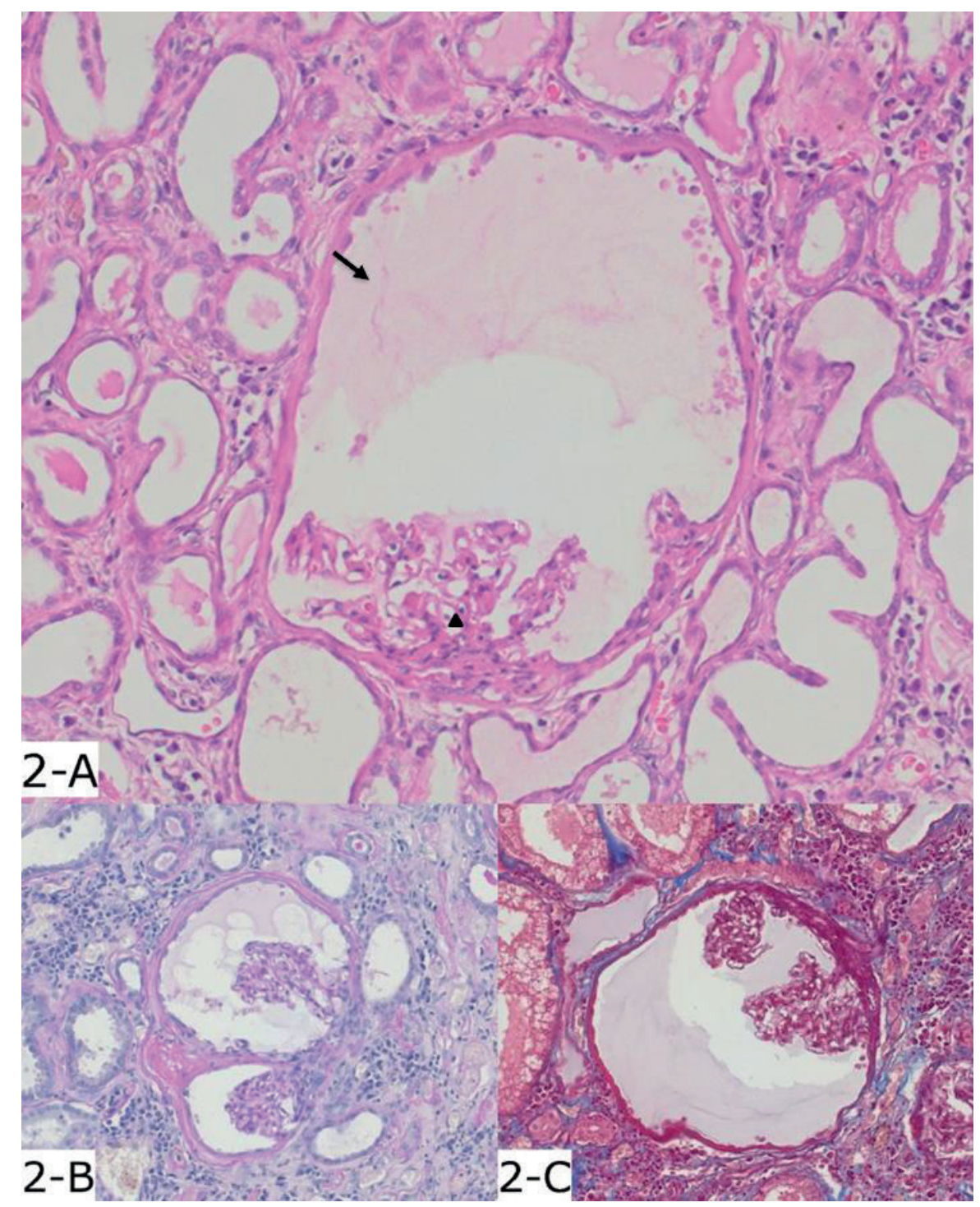

Figure 2. A-C: Glomerular atrophy, dog. 200X magnification. There is the enlarged capsular space with amorphous material inside (arrow), where the glomerular tuft is atrophied (arrowhead). A: Hematoxylin \& Eosin (HE) stain. B: Periodic Acid - Schiff (PAS) stain. C: Masson's Trichrome stain. 


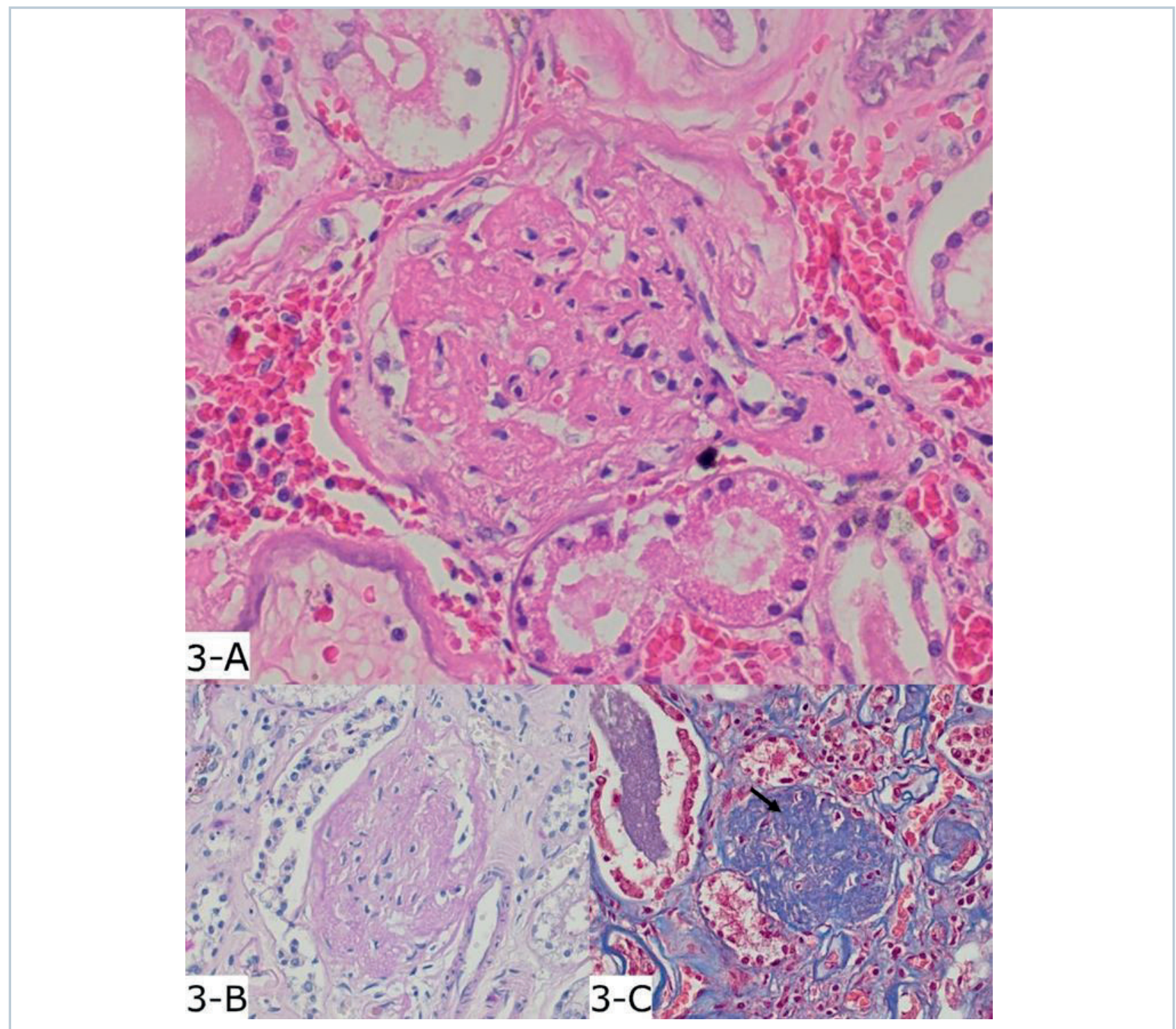

Figure 3. A-C: Glomerulosclerosis, dog. 400X magnification. There are a reduced and hypocellular glomerular tuft. A: The glomerular tuft has eosinophilic coloration in the Hematoxylin \& Eosin (HE) stain. (HE). B: Periodic Acid - Schiff (PAS) stain. C: Marked fibrosis notable through the blueish coloration (arrow). Masson's Trichrome stain.

One study has observed higher UPC in hypertense CKD patients (Bacic et al., 2010), which contradicts the results observed in this study. The more advanced the kidney injury, the more affected is the renin-angiotensin system (RAS) (Mitani, Yabuki, Taniguchi, \& Yamato, 2013), contributing to glomerular hypertrophy and sclerosis by inducing glomerular hypertension and fibrotic alterations (Kagami et al., 1997; Mahmood et al., 2006). In addition, it may induce mesangial and matrix proliferation (Mitani et al., 2013). In cats, more advanced stages of CKD are related with higher degrees of glomerulosclerosis (McLeland, Cianciolo, Duncan, \& Quimby, 2015). 
The most prevalent injury observed in thisstudywasmembranousglomerulonephritis (Figures 4). This group presented the second highest mean arterial blood pressure at 142.08 $\pm 31.0 \mathrm{mmHg}$, probably due to five animals in the group presenting systemic arterial hypertension. The mean serum albumin level was lower than in the other groups and the UPC presented a mean of $2.52 \pm 1.42$, which is, similar to the cases of atrophy, slightly higher than the cases of glomerulosclerosis and lower than the cases of membranoproliferative injuries and amyloidosis. The serum creatinine value was the lowest of all groups.

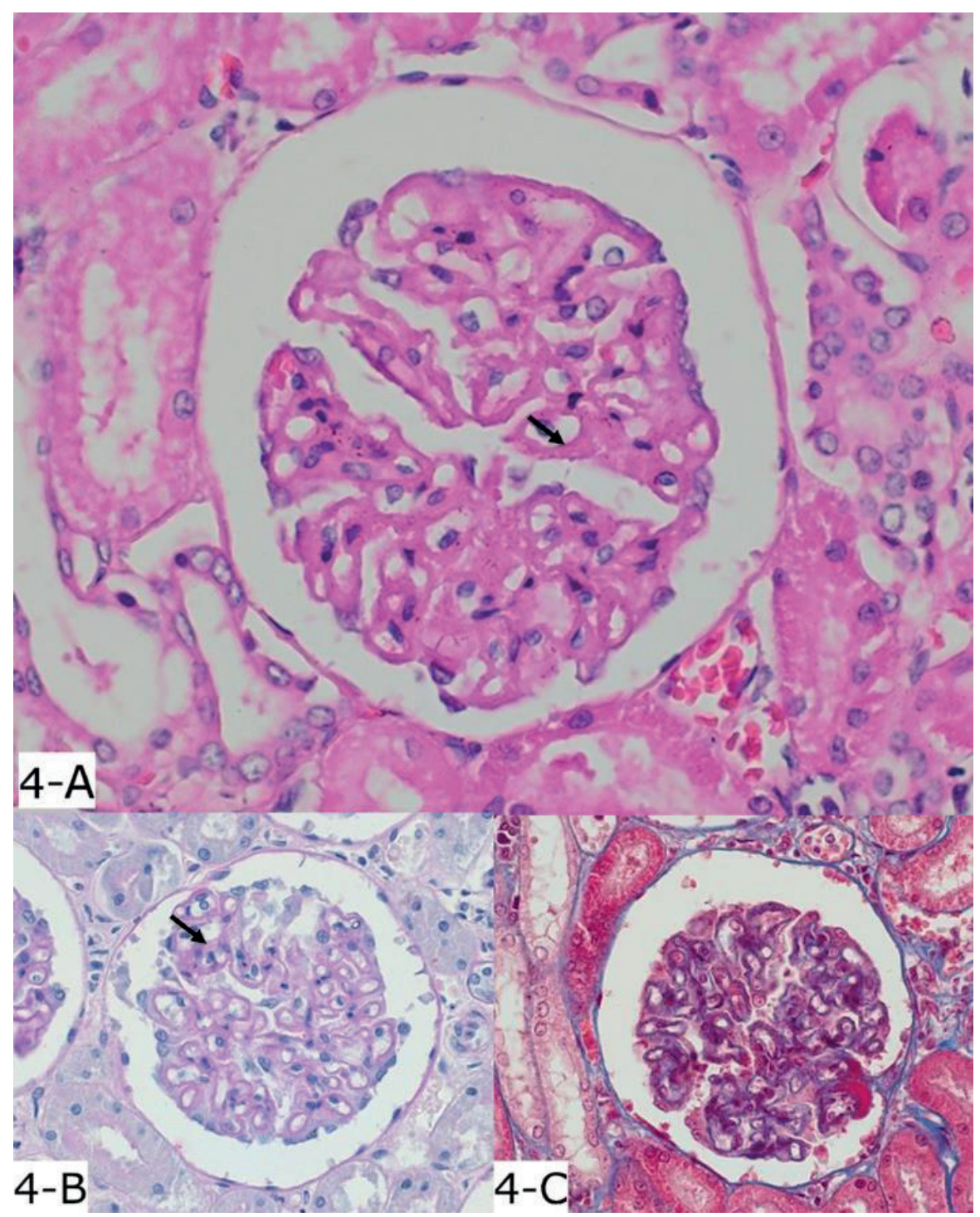

Figure 4. A-C: Membranous glomerulonephritis, dog. 400X magnification. The arrow indicates thickening of the glomerular basement membrane. A: Hematoxylin \& Eosin (HE) stain. B: Periodic Acid - Schiff (PAS) stain. C: Masson's Trichrome stain. 
The morphologic results observed in the membranous injuries are similar to those described by R. E. Cianciolo et al. (2016a). Jaenke \& Allen(1986) reported membranous glomerular injuries, which are the most common glomerular alteration associated with immune mechanisms, in about a third of the cases.

R. E. Cianciolo et al. (2016a) observed mean serum albumin values lower than the reference limits, and higher mean UPC values in the group with membranous alterations. Creatinine was the lowest mean value between the groups, which is in line with this study, but the values were lower in this study probably due to the fact that the biopsies were conducted with the animals still alive and suffering from proteinuria for diagnostic purposes, which differs from this study, which used dead animals.

In more advanced cases, there is a progressive thickening of the basement membrane of the glomerular capillaries incorporating the deposits of immunocomplexes, either evolving towards recovery or progressing to glomerulosclerosis. The more advanced the stage, the more marked is the azotemia. Hypoalbuminemia and proteinuria were more severe in the initial stages of membranous nephropathy (Jaenke \& Allen, 1986). In humans, it represents one of the main causes of nephrotic syndrome, mainly due to the formation of subepithelial immunocomplexes (preformed, formed in situ or antibodies against the antigen of the podocyte membrane), better evidenced in electronic microscopy (Lai et al., 2015) and associated with autoimmune diseases, infections, some drugs and neoplasms in $20 \%$ of the cases, while the remained is strictly autoimmune (Couser, 2017). However, about three quarters of the cases have idiopathic origin (Lai et al., 2015). The presence of these immunocomplexes activate the complementary system, initiating the glomerular damage, which evolves into CKD within a few years in about 30 to $40 \%$ of the cases (Lai et al., 2015).

The last group was classified as membranoproliferative glomerulonephritis (Figures 5), which is characterized by endocapillary hypercellularity. This group presented the lowest mean serum albumin value, the second highest mean UPC, the second highest mean serum creatinine value and no cases of high blood pressure. 


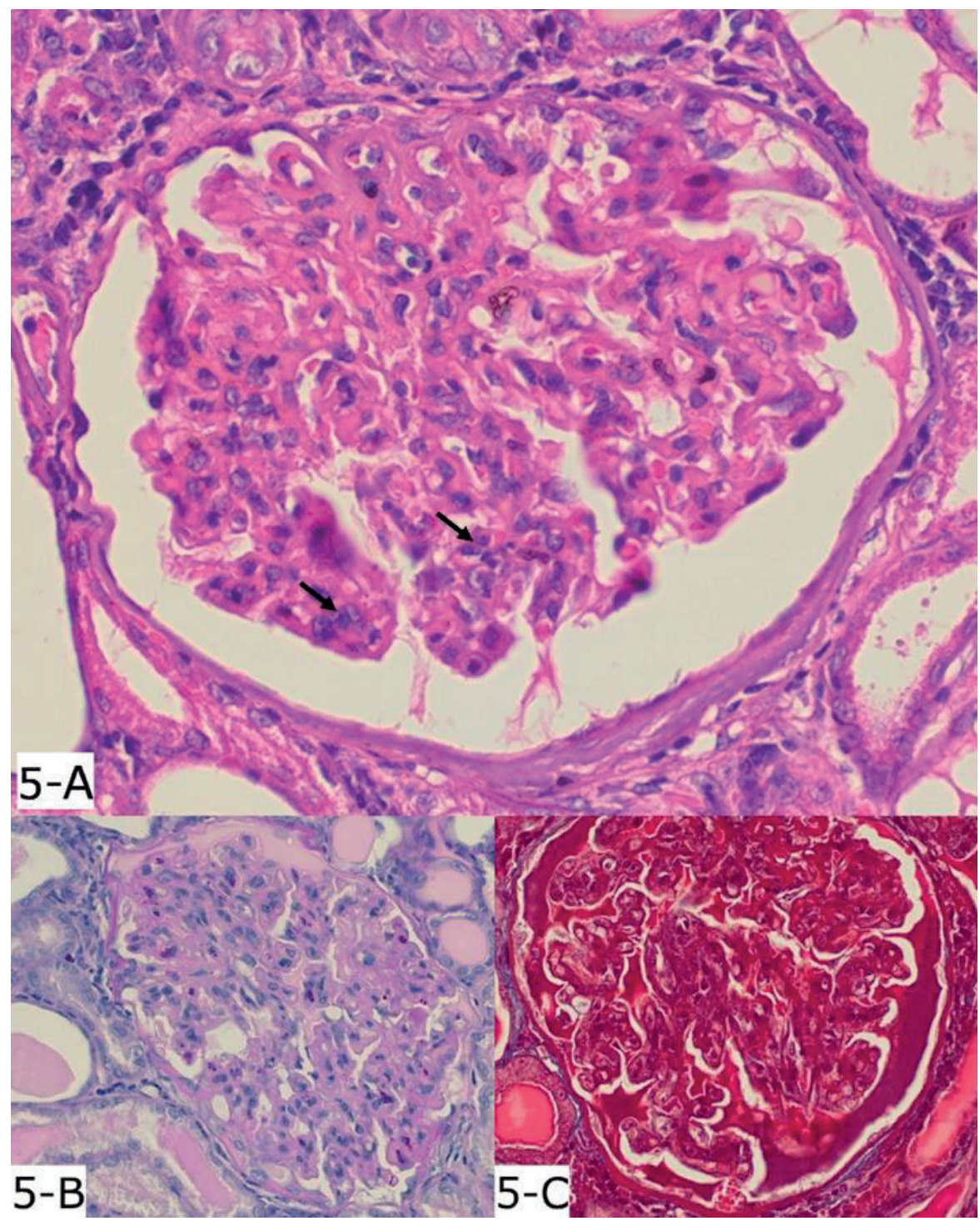

Figure 4. A-C: Membranoproliferative glomerulonephritis, dog. 400X magnification. There are mesangial and endocapillary hypercellularity (arrow). The capillaries present luminal compression due to the mesangial expansion and the thickening of the glomerular basement membrane. A: Hematoxylin \& Eosin (HE) stain. B: Periodic Acid - Schiff (PAS) stain. C Masson's Trichrome stain.

In the membronoproliferative injuries, as was the case in the study by R. E. Cianciolo et al. (2016a), a higher rate of cases with hypercellularity, thickening of the basement membrane, sclerosed glomeruli, fibrosis and interstitial inflammation were observed. There were also the presence of crystals and calcification and, in one of the cases, a cyst. All cases presented proteinaceous material in the tubule and glomerular capsular space.

In this group, there were no cases of high blood pressure, which differs from the findings of R. E. Cianciolo et al. (2016a), in 
which almost all animals were hypertense and with UPC similar to the membranous injury group, but the creatinine levels in this group was higher, closer to the levels observed in this study.

Through electronic microscopy, it is possible to classify the cases into subtypes according to the location where the immunocomplexes are deposited (Sethi \& Fervenza, 2012). Hokamp et al. (2016) have noted that the UPC has been significantly associated with immune-mediated glomerulonephritis. UPC was higher in cases of amyloidosis, followed by immune-mediated glomerulonephritis (Schneider et al., 2013). Hokamp et al. (2016) concluded that the serum albumin values were also lower in dogs with immune-mediated glomerulonephritis than in other types of glomerular injuries.
The distinction between immunemediated and non-immune-mediated glomerulonephritis is difficult with optical microscopy due to the overlapping of injuries or subtle injuries depending on the stage of the disease. Recent immunemediated cases with proteinuria may not have happened long enough for remodeling of the glomerular basement membrane to happened. Likewise, there are cases not mediated by immunocomplexes in which there is generalized hypercellularity or thickening of the basement membrane of the glomerulus (Cianciolo et al., 2013).

The "Membranous" group, which had the highest number of animals, was compared with the "Other" group, which was comprised of the remaining injuries observed in the study due to the high variability and small sample size. The clinical and laboratory findings for both groups are both found in Table 3 .

Table 3

Scores for the clinical and laboratory parameters for the "Membranous" group and the "Others" group, which encompasses amyloidosis, glomerular atrophy, glomerulosclerosis and membranoproliferative injuries

$\begin{array}{lcccc}\text { Groups } & \begin{array}{c}\text { Albumin } \\ (\mathrm{g} / \mathrm{dL})\end{array} & \text { PCR } & \begin{array}{c}\text { Creatinine } \\ (\mathrm{mg} / \mathrm{dL})\end{array} & \begin{array}{c}\text { Blood Pressure } \\ (\mathrm{mmHg})\end{array} \\ \text { Others }(\mathrm{n}=7) & & 2.56 & 9.13 & 140 \\ \text { Median } & 2.3 & 1.04-20.22 & 5-13 & 125-200 \\ \text { Minimum - Maximum } & 2-2.5 & 2.22 & 5.82 & 145 \\ \text { Membranous ( } \mathrm{n}=17) & 2.1 & 0.52-5.9 & 0.69-14 & 90-190 \\ \text { Median } & 1.3-3.1 & 0.5700 & 0.0658 & 0.9623 \\ \text { Minimum - Maximum } & 0.2971 & & \end{array}$

The values are presented as median, minimum and maximum. Comparisons for P value made between the "membranous" group and the "others" group. 
No significant differences were observed between the membranous glomerular injuries and the remaining injuries, as was the case in the study by R. E. Cianciolo et al. (2016a). UPC did diverge between the groups. Animals with renal amyloidosis were among those with the lowest systolic arterial blood pressure and animals with membranoproliferative injuries were among those with highest UPC, which is in line with the findings observed in this study. The lowest mean serum albumin value observed was in the group with membranoproliferative injuries, which differs from this study (R. E. Cianciolo et al., 2016a).

In the study conducted by Hokamp et al. (2016), the group containing animals with glomerular atrophy presented higher creatinine levels than the remaining kinds of injury, which is similar to the findings of this study, in which the "others" group presented the highest creatinine value.

\section{Conclusion}

Within cases of chronic kidney disease there may be different types of glomerular injuries that lead to a similar clinical and laboratoryprofile.Inthisstudy, dogswithchronic kidney disease presented predominantly membranous glomerular injuries, followed by glomerulosclerosis, membranoproliferative injuries, glomerulocystic atrophy and amyloidosis.

\section{References}

Acierno, M. J., Brown, S., Coleman, A. E., Jepson, R. E., Papich, M., Stepien, R. L., \& Syme, H. M. (2018). ACVIM consensus statement: guidelines for the identification, evaluation, and management of systemic hypertension in dogs and cats. Journal of Veterinary Internal Medicine, 32, 18031822. doi: $10.1111 /$ jvim. 15331

Aresu, L., Pregel, P., Bollo, E., Palmerini, D., Sereno, A., \& Valenza, F. (2008). Immunofluorescence staining for the detection of immunoglobulins and complement (C3) in dogs with renal disease. Veterinary Record, 163, 679683. doi: 10.1136/vr.163.23.679

Bacic, A., Kogika, M. M., Barbaro, K. C., luamoto, C. S., Simões, D. M. N., \& Santoro, M. L. (2010). Evaluation of albuminuria and its relationship with blood pressure in dogs with chronic kidney disease. Veterinary Clinical Pathology, 39(2), 203-209. doi: 10.1111/j.1939-165X.2009.00207.x

Bartges, J. W. (2012). Chronic kidney disease in dogs and cats. Veterinary Clinics of North America: Small Animal Practice, 42(4), 669692. doi: 10.1016/j.cvsm.2012.04.008

Cavalcante, L. F. H., Neuwald, E. B., Mello, F. P. S., Lacerda, L. A., Oliveira, S. T., Marques, J. M. V., \& Pöppl, A. G. (2006). Síndrome nefrótica em cão associada à Babesia canis. Acta Scientiae Veterinariae, 34(3), 335338. doi: 10.22456/1679-9216.15556. Retrieved from https://www.researchgate. net/publication/292681789_Sindrome_ nefrotica_em_cao_associada_a_ Babesia_canis_Nephrotic_syndrome_in_ dog_associated_Babesia_canis

Chalifoux, A., Phaneuf, J. B., Olivieri, M., \& Gosselin, Y. (1982). Glomerular polycystic kidney disease in a dog (blue merle collie). The Canadian Veterinary Journal, 23(12), 365-368. Retrieved from https:// www.ncbi. nlm.nih.gov/pmc/articles/PMC1790272/ pdf/canvetj00289-0043.pdf 
Cianciolo, R. E., Brown, C. A., Mohr, F. C., Spangler, W. L., Aresu, L., van der Lugt, J. J.,... Lees, G. E. (2013). Consensus statement - pathologic evaluation of canine renal biopsies: methods for identifying features that differentiate immune-mediated glomerulonephritides from other categories of glomerular diseases. Journal of Veterinary Internal Medicine, 27, 10-18. doi: 10.1111/jvim.12 226

Cianciolo, R. E., Mohr, F. C., Aresu, L., Brown, C. A., James, C., Jansen, J. H.,... Lees, G. E. (2016a). World small animal veterinary association renal pathology initiative: classification of glomerular diseases in dogs. Veterinary Pathology, 53(1), 113135. doi: $10.1177 / 0300985815579996$

Cianciolo, R., Hokamp, J., \& Nabity, M. (2016b). Advances in the evaluation of canine renal disease. The Veterinary Journal, 215, 21 29. doi: 10.1016/j.tvjl.2016.04.012

Confer, W., \& Panciera, J. (2001). The urinary system. In D. McGavin, W. Carlton, \& J. Zachary, Thomson's special veterinary pathology (pp. 235-278) St. Louis: Missouri: Mosby.

Couser, W. G. (2017). Primary membranous nephropathy. Clinical Journal of the American Society of Nephrology, 12(6), 983-997. doi: 10.2215/CJN.11761116

DiBartola, S. P., Tarr, M. J., Webb, D. M., \& Giger, U. (1990). Familial renal amyloidosis in Chinese Shar Pei dogs. Journal of the American Veterinary Medical Association, 197(4), 483-487. Retrieved from https://www.researchgate.net/ publication/20945353 Familial renal amyloidosis_in_Chinese_Shar_Pei_dogs
Hokamp, J. A., Cianciolo, R. E., Boggess, M., Lees, G. E., Benali, S. L., Kovarsky, M., \& Nabity, M. B. (2016). Correlation of urine and serum biomarkers with renal damage and survival in dogs with naturally occurring proteinuric chronic kidney disease. Journal of Veterinary Internal Medicine, 30(2), 591-601. doi: 10.1111/ jvim.13832

International Renal Interest Society (2019). Staging of CKD (modified 2019). Retrieved from http://www.iris-kidney.com/pdf/IRIS Staging_of_CKD_modified_2019.pdf

Jaenke, R. S., \& Allen, T. A. (1986). Membranous nephropathy in the dog. Veterinary Pathology, 23(6), 718-733. doi: 10.1177/030098588602300611

Jennette, J., \& Schwarts, M. (2007). Primer on the pathologic classification and diagnosis of kidney disease. In: J. C. Jennette, J. L. Olson, \& M. M. Schwarts (Eds.), Heptinstall's pathology of the kidney (pp. 97-124). Filadélfia: Pensilvânia. Lippincott Williams \& Wilkins.

Kagami, S., Kuhara, T., Okada, K., Kuroda, Y., Border, W. A., \& Noble, N. A. (1997). Dual effects of angiotensin II on the plasminogen/plasmin system in rat mesangial cells. Kidney International, 51(3), 664-671. doi: 10.1038/ki.1997.96

Lai, W. L., Yeh, T. H., Chen, P. M., Chan, C. K., Chiang, W. C., Chen, Y. M.,... Tsai, T. J. (2015). Membranous nephropathy: a review on the pathogenesis, diagnosis, and treatment. Journal of the Formosan Medical Association, 114(2), 102-111. doi: 10.1016/j.jfma.2014.11.002 
Mahmood, J., Khan, F., Okada, S., Kumagai, N., Morioka, T., \& Oite, T. (2006). Local delivery of angiotensin receptor blocker into the kidney ameliorates progression of experimental glomerulonephritis. Kidney International, 70(9), 1591-1598. doi: 10.1038/sj.ki.5001872

Maia-Elkhoury, A. N. S., Alves, W. A., SousaGomes, M. L., Sena, J. M., \& Luna, E. A. (2008). Visceral leishmaniasis in Brazil: trends and challenges. Cadernos de Saúde Pública, 24(12), 2941-2947. doi: 10. 1590/S0102-311X2008001200024.

McLeland, S. M., Cianciolo, R. E., Duncan, C. G., \& Quimby, J. M. (2015). A comparison of biochemical and histopathologic staging in cats with chronic kidney disease. Veterinary Pathology, 52(3), 524-534. doi: 10.1177/0300985814561095

Mitani, S., Yabuki, A., Taniguchi, K., \& Yamato, O. (2013). Association between the intrarenal renin-angiotensin system and renal injury in chronic kidney disease of dogs and cats. The Journal of Veterinary Medical Science, 75(2), 127-133. doi: 10. 1292/jvms.12-0314

Polzin, D. J. (2013). Evidence-based step-wise approach to managing chronic kidney disease in dogs and cats. Journal of Veterinary Emergency and Critical Care, 23(2), 205-215. doi: 10.1111/vec.12034

Polzin, D. J., \& Cowgill, L. D. (2013). Development of clinical guidelines for management of glomerular disease in dogs. Journal of Veterinary Internal Medicine, 27, 2-4. doi: 10.1111/jvim.12225

Rivas, A. L., Tintle, L., Kimball, E. S., Scarlett, J., \& Quimby, F. W. (1992). A canine febrile disorder associated with elevated interleukin-6. Clinical Immunology and Immunopathology, 64(1), 36-45. doi: 10. 1016/0090-1229(92)90057-U

Salinas, E. M., Ramírez, L. I. M., Ortuño, L. E. G., Díaz, A. C. N., \& González, L. A. C. (2008). Enfermedad glomeruloquística en dos perros con insuficiencia renal Glomerulocystic. Veterinaria México, 39(1), 97-109. Recuperado de http://www. scielo.org.mx/scielo.php?script $=$ sci arttext\&pid=S0301-509220080001 00009

Santos, F., Coppede, J. S., Pereira, A. L, Oliveira, L. P., Roberto, P. G., Benedetti, R. B.,... Marins, M. (2009). Molecular evaluation of the incidence of Ehrlichia canis, Anaplasma platys and Babesia spp. in dogs from Ribeirão Preto, Brazil. The Veterinary Journal, 179(1), 145-148. doi: 10.1016/j.tvjl.2007.08. 017

Schneider, S. M., Cianciolo, R. E., Nabity, M. B., Clubb, F. J. J., Brown, C. A., \& Lees, G. E. (2013). Prevalence of immune-complex glomerulonephritides in dogs biopsied for suspected glomerular disease: 501 cases (2007-2012). Journal of Veterinary Internal Medicine, 27, S67-S75. doi: 10. $1111 /$ jvim. 12247

Sethi, S., \& Fervenza, F. C. (2012). Membranoproliferative glomerulonephritis a new look at an old entity. The New England Journal of Medicine, 366(12), 1119-1131. doi: 10.1056/NEJMra1108178

Silva, M. L., Costa, C. L., Cintra, C. A., Souza, G. A. C., Ribeiro, G. F., Heitor, T. F.,... Crivellenti, L. Z. (2015). Alterações glomérulo-tubulares em cães infectados por Ehrlichia Canis. Investigação, 14(6), 17-21 doi: 10.26843/ investigacao.v14i6.923 
Slauson, D. O., Gribble, D. H., \& Russell, S. W. (1970). A clinicopathological study of renal amyloidosis in dogs. Journal of Comparative Pathology, 80(2), 335-343. doi: 10.1016/0021-9975(70)90104-0

Szczepankiewicz, B., Pasławska, U., Grzegory, M., Jonkisz, P., Borecka, P., Marzec, M.,... Nowak, M. (2018). Canine renal amyloidosis: a case report. Medycyna Weterynaryjna, 74(5), 320-323. doi: 10. 215 21/mw.6038
Takahashi, M., Morita, T., Sawada, M., Uemura, T., Haruna, A., \& Shimada, A. (2005). Glomerulocystic kidney in a domestic dog. Journal of Comparative Pathology, 133(2-3), 205-208. doi: 10.1016/j.jcpa. 2005.01.014

Vaden, S. L., \& Elliott, J. (2016). Management of proteinuria in dogs and cats with chronic kidney disease. Veterinary Clinics of North America: Small Animal Practice, 46(6), 1115-1130. doi: 10.1016/j.cvsm. 2016.06.009 
